\title{
Review of the Book: The Institutional Unconscious
}

\author{
Henrique Guilherme Scatolin \\ PUC-SP (Pontificate Catholic University of São Paulo), São Paulo, Brazil
}

This book is the result of the reformulated minutes of the II International Symposium of Psychoanalysis, Groups and Institutions that occurred at the beginning of the 80s in the city of Rio de Janeiro.

In the introduction, Baremblitt brings some features of the institutionalist movement, alerting the reader to its conceptual genesis in which there is a historical and dialectical materialism, occurring criticisms to the production modes, the State role and the family. Therefore, this movement was developed "as the unofficial option within the state capitalism, of various social democracies, of transition systems and the socialism..." (1982, p. 19). It behooved the institutionalists to criticize the most extensive explanations, since they did not aim to explain complex and concrete social situations, such as the production means. Consequently, they would develop singular resources to understand and intervene in each group.

Baremblitt brings four roundtables. At the first table, entitled Current Status of Individual and Group Psychoanalysis, the coordinator, Luis Fernando de Mello Campos, and the participants Gregório Baremblitt, Armando Bauleo, Eduardo Pavlovsky, and Osvaldo Saidon are present.

Bauleo brings the discussion on group psychoanalysis, in which he points the psychoanalysis in group and the psychoanalysis of the group. While in the psychoanalysis in group, there is a search for the understanding of individuals isolated in a group, in the psychoanalysis of the group, there is a search for the group psychoanalytic understanding.

At this point, Pavlovsky makes a historical resume in the group psychoanalysis history, making a serious criticism to the Bion theory of groups. He brings the self-management system, a system in which the supervision was precarious in its beginning, as he says: "We were not looking for a supervisor because we trusted that someone who did not do group psychotherapy came to teach us how to do group psychology" (1982, p. 30). One way was to adopt dramatic techniques. Therefore, he points out that the group psychotherapy is a practice that enables and requires the theorization in terms of a social-historical unconscious interlaced with the forces and work-related representations, to power and money.

The participant Saidon reiterates the criticism to Bion, making a criticism to the classic exercise of individual psychoanalysis, resuming the criticisms of Besaglia to the orthodox psychoanalysis, and highlighting the influences of the institutionalist currents and of democratic psychiatry in Brazil. Bauleo reiterates the wise criticism of Saidon, since, when it comes to group structure, he emphasizes that it is necessary to insist that it is organized due to the differences between the subjects.

Finally, in the institutional field, Lourau differentiates the analysis field and the intervention field. While in the analysis field, there is a grouping of materials and the production of knowledge about a particular conjuncture; in the intervention field, there is the deployment of a concrete operating device enabling a generalized collective analysis. So, the intervention field is a "polymorphic and heterogeneous device intended 
to deconstruct the established and promote new unusual articulations" (1982, p. 56).

At the second table entitled Current Panorama of the Institutional Movement are the coordinator Heliana Conde and the participants Gregório Baremblitt, Gérad Mendel, René Lourau, and J. A. Guilhon de Albuquerque. They discussed the institutionalist movement, resuming the political issues and emphasizing the institutional analysis characteristics. Lourau brings the beginning of investigations in the educational area, emphasizing the psycho-sociological model inspired in the American groups' dynamics, and stressing the self-management and the analyzer concepts, as he says: "The self-management is very important in the socio-analytic intervention mechanism, since it refers to the performance of the entire operation, both its demand and the socio-analysts' fees payment" (1982, p. 76). So the analyzer would bring the analysis resolution, and before the intervention, the order and the demand would arise. The order would be the result of the institutional power, emerging before the intervention. And the demand would occur along the interventions, connected to the social classes and their struggles.

Baremblitt resumes the word, highlighting the IBRAPSI (Brazilian Institute of Psychoanalysis, Groups and Institutions) value, pointing out that the institutional analysts' need to encompass a growing number of the population through institutional interventions.

At the roundtable number III, Osvaldo Saidon and the participants Gregório Baremblitt, Armando Bauleo, René Loureau, Gérad Mendel and Alejando Scherzer were present. In this table, they emphasized the "critical-productive articulations between the individual, group and institutional interventions" (1982, p. 99). The coordinator opens this table, stating that all analysis need "to include the group institutional dimension both from the instituted and from the instituting perspectives" (1982, p. 99). So the group must be studied in its heterogeneity and its openness, and cannot be considered a homogenous and totalizing structure. The group needs to be a tactical space where one can see the unique, unusual, and creative effects production, being its production and repetition (or stereotypy) an alternative for it.

These statements are completed by Professor Alejandro Scherzer who brings his experience with coupes, therapeutic groups, and operating groups. He understands the group as "a set of people, who meet for a certain time, in a certain place, in a social context, to perform multiple tasks... The group is an organization in which numerous institutions are corporified" (1982, pp. 101-102). So, the group would be a space of institutional interweaving, in which we have political, economic, and ideological determinations of the social set.

Upon returning the word to Mendel, this researcher stresses that the institutional analysis must be concerned with institutional relations in which the groups and its various collectivities are constituted. The groups could produce the regression phenomena among its members, in which the policy analysis can come from a kind of complicity that is "not conscious between the coordinator and the members of his group" (1982, p. 109).

This speech continues in table IV, which is entitled Current Status of Psychiatry Institution and the Psychiatric Establishments. This table includes the coordinator, Baremblitt, and the participants Armando Bauleo, José Augusto Guilhon de Albuquerque, Osvaldo Saindon, Alejandro Scherzer, and Luis Fernando de Mello Campos.

In this table, Baremblitt introduces the exodus of the Jewish people to approach the institutions. Guilhon resumes the word, emphasizing that the institutional object "constitutes in the fabric, in the network of this and other existing institutions that determine it" (1982, p. 138). In this object, there is the legitimating discourse of institutional practices, being mentioned as an example, the electroshock therapy used in the 50s in psychiatric 
institutions.

If, on one hand, Mendel points out the regression in the group, on the other, Campos defines some aspects of the institution, ensuring that this is defined by the practices developed and the articulation between them. Therefore, the way in which the institution defines its object and its legitimating discourse is of utmost importance for its effectiveness.

At this point, Saidon resumes the word, highlighting his experiences in psychiatric hospitals and emphasizing the denunciation instruments that many use from the therapeutic groups in these hospitals. He interprets that it denounces the precariousness of transfer analysis due to the lack of commitment of some institutional analysts.

Bauleo, another participant in this table, resumes the law 180 promulgated in Italy aiming the abolition of asylums. This opening, according to this author, would be "as an end and a beginning in the psychiatry history" (1982, p. 149). This opening, according to the participants, should be complemented as a movement that goes to the community to create in it conditions to recycle and innovate the process within the institutions.

This table ends criticizing the Argentinean and European bourgeoisie, portraying that the social exclusion is also a result of the system and the order imposed by the State. For this purpose, he uses a beautiful metaphor: "It seems ridiculous to believe that a small puff can drill into a wall. But... it was the wind that made the mountains emerge. One should have the patience of the winds and blow them all at the same time. Men are generally less hard than the stones" (1982, p. 162).

\section{References}

Baremblitt, G. F. (1982). O Inconsciente Institucional. Petrópolis: Vozes. Reseña del libro: El Inconsciente Institucional. 